
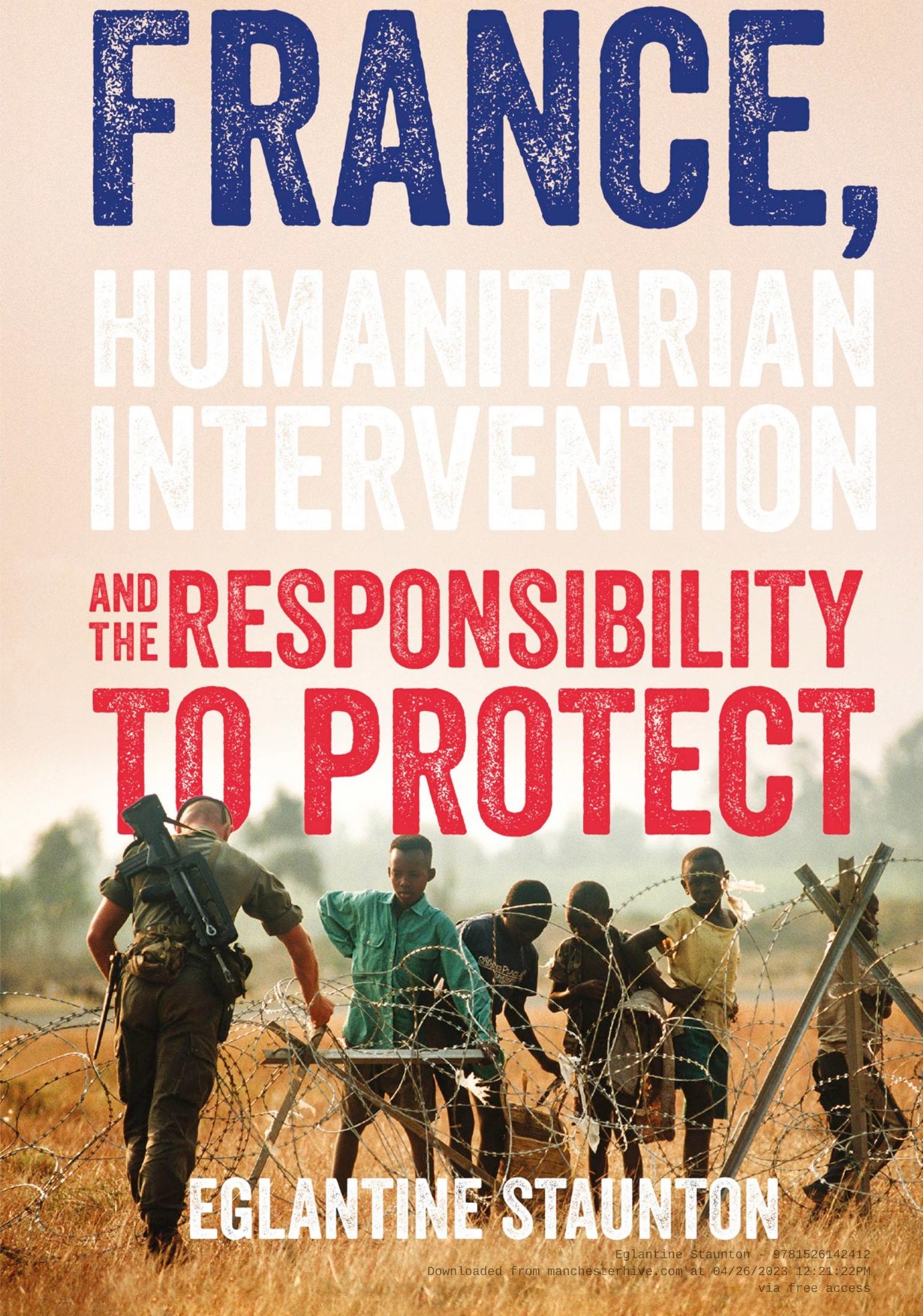


\section{France, humanitarian intervention and the responsibility to protect}

\section{MANCHESTER 1824}

Manchester University Press 
Eglantine Staunton - 9781526142412 Downloaded from manchesterhive.com at 04/26/2023 12:21:22PM 


\title{
France, humanitarian intervention and the responsibility to protect
}

\author{
Eglantine Staunton
}

Manchester University Press 


\title{
Copyright () Eglantine Staunton 2020
}

The right of Eglantine Staunton to be identified as the author of this work has been asserted by her in accordance with the Copyright, Designs and Patents Act 1988.

\author{
Published by Manchester University Press \\ Altrincham Street, Manchester M1 7JA \\ www.manchesteruniversitypress.co.uk \\ British Library Cataloguing-in-Publication Data \\ A catalogue record for this book is available from the British Library
}

ISBN 9781526142405 hardback

First published 2020

The publisher has no responsibility for the persistence or accuracy of URLs for any external or third-party internet websites referred to in this book, and does not guarantee that any content on such websites is, or will remain, accurate or appropriate.

IMAGE: A French soldier, one of the international force supporting the relief effort for Rwandan refugees, adjusts concertina wire in August 1994.

PHOTO BY: SSGT ANDY DUNAWAY/DoD

$$
\text { Typeset }
$$

by Toppan Best-set Premedia Limited 